\title{
InNOVATIVE PM APPROACH TO PRODUCE AN EnVironmentally Friendly Product
}

\author{
MAJstorovic, V.; Medic, M. \& BANDiC G. M.
}

Abstract: When carrying out any project today, it is necessary to think about environmentally friendly project result. With environmental, legal and market requirements placed in front of projects, understanding of the application of different approaches to project management (PM) is also significantly changed. In addition to the implementation of formal PM process, there are more and more solutions introduced for specific environment in which the project is running. Thinking on environmentally friendly project result can be encouraged or caused by various organizational approaches to the environmental problems and ways of its protection, which requires a constant innovation of management approaches and processes. This can lead to innovative approach to PM when a new product is created, based on the integration of different organizational approaches to the environment protection in PM system, what will be presented in this paper.

Key words: project management, environment, product, innovation, approach
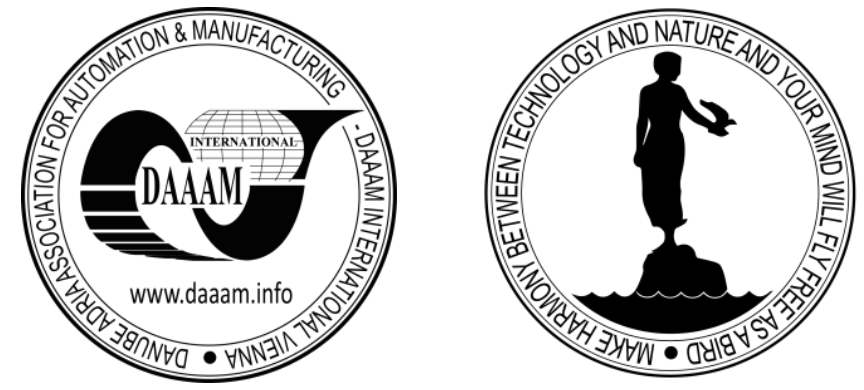

Authors' data: Dr. Sc. Majstorovic, V[lado]*; Dipl. Iur. Medic, M[aja]**; Dipl. Ing. Bandic Glavas, M[arijana]***, *University of Mostar, Trg hrvatskih velikana 1, 88000, Mostar, BiH, ** University of Mostar, Trg hrvatskih velikana 1, 88000, Mostar, $\mathrm{BiH}, * * *$ Faculty of Mechanical Engineering and Computing, University of Mostar, Matice hrvatske bb, 88000, Mostar, BiH, vlado.majstorovic@tel.net.ba, maja.medic.mo@gmail.com, marijana.bandic@gmail.com

This Publication has to be referred as: Majstorovic, V[lado]; Medic, M[aja] \& Bandic Glavas, M[arijana] (2015). Innovative PM Approach to Produce an Environmentally Friendly Product, Chapter 36 in DAAAM International Scientific Book 2015, pp.423-430, B. Katalinic (Ed.), Published by DAAAM International, ISBN 978-3-902734-05-1, ISSN 1726-9687, Vienna, Austria

DOI: $10.2507 /$ daaam.scibook.2015.36 


\section{Introduction}

Today we are faced with increasing environmental problems such as reduction of natural resources, global warming, environmental pollution, problems with waste management and others. On the other hand, the level of knowledge in various fields of science and state-of-the-art of technology is so advanced that we can talk about solutions that can protect the environment and prevent its pollution.

It is necessary to think about environmental protection when the project is running, because the projects that are not based on environmental awareness are not only in conflict with the legal framework, but they are usually not accepted by the end users. With environmental, legal and market demands that are placed in front of the projects, understanding of project management methodology has significantly begun to change. It is not only the need for the implementation of formal project management processes, but solutions for specific environment in which the project takes place have already been introduced. For example, for successful work on projects that result in new products, in addition to immediate areas of project management, project environment and the legal framework, not only the pollution that is created during the creation of a product should be taken into account, but also the method of disposal of wastes during the project implementation and the vision of product treatment after its use.

Such thinking about environmentally friendly project result can be encouraged or caused by various organizational approaches to the environmental problems and ways of its protection. All this requires constant innovation and creation of management processes. In this way we can get improved approach to project management that is based on integration of the organizational approaches to environmental protection in the project management system.

\section{Project management approaches}

In recent literature we can find a general classification into three basic approaches to project management: the traditional approach (TPM), an extreme approach (XPM) and adaptive approach (APF). (Wysocki \& McGary, 2003)

\subsection{Traditional approach}

The traditional approach to project management is based on people managing, which is the same as management in general (Wysocki \& McGary, 2003). The traditional approach is considered as the basis for the division on phases or the groups of the processes according to the Project Management Institute (PMI) (PMBOK Guide, 2008): initiation, planning, execution, monitoring and control and closure of the project. The period in which, through these phases, project leads to the end is called project life cycle. The project life cycle is defined generically, in the simplest way possible. As it has already been mentioned, the initial stage, than one or more of intermediate stages and the final stage are noticed, and they are mutually connected by input-output data. 
It is especially necessary to point out the fact that the project management cycle and product life cycle are not the same because the project can be only one phase in the execution of a new product. Elaboration of the product life cycle results in defining of phases in the project execution, which are specific for various types of projects, while the cycles of project management, according to PMI, are universal and they are, in fact, subject of standardization proposed by this organization. The set of all phases of the project, according to the PMI, make the project life cycle. (Majstorović, 2010)

In traditional approach the plan is the basis of everything, because it represents not only the description of jobs and the time needed for their implementation, but also a tool for decision making. This approach is comprehensive and allows application in range from the simplest to the most complex projects, because during the project identical steps are always applied. However, because of that very fact, the need for other approaches has arised, since "no one size fits all" and project managers must adapt the basic principles on which the project management is based to the changes in order to avoid waste of time and money. (Wysocki \& McGary, 2003)

The biggest problem we face within the traditional approach is the difference between wants and needs of users, because what the user wants is often not what he needs, and during the project life cycle it happens that users understand that what they have been looking for is not what they need and they want to change the requirements. There is a need for approach that incorporates all new changes in the life cycle, and it enables learning and improving throughout the project life cycle, and not blindly sticking to the original plan.

\subsection{Extreme approach}

This approach includes major changes and complex situations where the speed is important for success. The development of new products, as well as research and development of projects are undoubtedly parts of this category. (Wysocki \& McGary, 2003)

The whole discipline called agile project management has been developed around this kind of approach to project management. Agile project management includes various methods such as Extreme Programming, which has only one goal, to complete the project, SCRUM, based on rugby and concentrates only on the organization of the teams, the Dynamic System Development Method (DSDM), which initially sets the time and available resources, and thus adjusts the amount and functionality and others. They are all focused on the projects of extreme software development.

In 2001 a group of authors issued a Manifesto for Agile Software Development in which they set four fundamental values of agile management: people and relationships ahead of the processes and tools, the product that "works" in front of extensive documentation, cooperation with the user in front of negotiations about the agreement, responding to the changes ahead plan tracking. (Manifesto, 2015) This does not mean that the processes, tools, documentation, negotiation and plan are unimportant but they are less important. Although the Manifesto was written primarily for agile software development, core values can be applied directly, with minor changes, on the agile project management. (Špundak, 2015) 
Model for Agile project management is based on the traditional model and its five phases, but these phases are replaced with more appropriate ones (Padavić et al.,2011) (Špundak, 2015):

- Envision - to determine the vision and scope of the project, the project team members and project organization (instead of the initial phase, to emphasize the importance of vision);

- Speculate - to estimate requirements and functionality of the future software (the product), to estimate amount of work for certain requirements, a draft plan of delivery, risks and risk mitigation strategies and project costs (instead of planning, to emphasize the uncertainty because the plan is linked to the definiteness);

- Explore - represents the product development. Exploring is a word that describes the essence of the idea of agile development. The goal is to create the product, not according to a well-defined plan, but with the cooperation of the end-user, through the process of development to explore and discover what the user actually needs (instead of control, because the research is outlined as iterative, that is, nonlinear);

- Adapt - adapting to changes, whether it is the changes in the environment system that we produce product for, or the changes in the perception of the final project and real needs of the users;

- Close - agile methods emphasize the completion of all outstanding tasks, the finalization of the necessary documentation and most importantly, the communication and relationships within the team.

Agile methods emphasize the iterative approach to the project and they are suitable for projects of various sizes. They place the emphasis on stronger communication and creation of useful product, while strict frameworks of predefined project phases and extensive documentation are of the secondary importance. Practice has shown that the practice of agile methods can increase the success rate of projects, because the team in active communication with the user and by responding to changes in requirements arising in the project implementation gaines better insight into the actual user needs and thus creates a product that is harmonized with the user expectations.

However, there are some problems that teams face, and they are related to the knowledge acquired in the work because there is no extensive documentation, big efforts that the user has to take since his involvement in the development is expected, ambiguities because there are no guidelines for creating an agile contract, and problems with financing and providing of the project budget, because the team is expected to comply with changes in the requirements, which can also mean the project time frame breaking. Because of that the need to develop an approach that will be less extreme has arisen.

\subsection{Adaptive project framework - customized approach}

In an effort to fill the gap between the two approaches, Adaptive Project Framework was created (Špundak, 2015).

Adaptive project framework is based on a plan which is completely followed, but contrary to traditional approach, the plan is not developed at the beginning, but in cyclic 
way during the project, while the time and costs are given at the beginning of the project. Thus, an adaptive project framework is cyclic and adaptive approach, which consists of five stages, and is intended to enable maximum business benefits to the users within time and cost limits. Phases of adaptive project framework are: reach of version, the cycle plan, the cycle development, user verification and review of the version. The fundamental guiding principle throughout the entire process is that the plan incorporates only those activities which are sure to be part of the final solution. In this way, a more detailed solution is reached in subsequent iterations. If it is necessary, the first cycle, or the iteration, in the process may be conceptual part as an introduction to other iterations of the project development. However, as well as most of methodologies, adaptive project framework is a way of thinking, directed towards the user. Fundamental values that must be respected in each project guided by this methodology are: focus on the user, process management is entrusted to the user, incremental results very quickly and very often, constant questioning, and the idea that change is progress towards a better solution and it is not necessary to speculate about the future. Such a set of core values puts the whole process in the framework in which it takes place, with a significant share of the user in the process and the continuous improvement of the existing solutions.

\section{Projects, environmental awareness, and different approaches to environmental protection}

It is necessary to think about environmental protection during implementation of each project, because projects that are not based on environmental awareness are not only in conflict with the legal framework, but they are usually not accepted by end users. Such thinking about environmentally friendly project result can be triggered or caused by various organizational approaches to environmental problems and ways of its protection. Initiatives that indicate growing environmental sensitivity and behavior are aimed to reduction and control of the impact that organizations have on the environment.

However, the level of environmental awareness and responsibility of organizations is different, which shows different organizational approaches to the environmental problems (Bahtijarević-Šiber et al., 2008): legal approach - a relatively small number of organizations care for environmental issues, limited just to respect the law and legal provisions; market approach - increased environmental awareness of the organizations related to the users' demands and their satisfaction, which is the condition for survival in the market and competitiveness; stakeholders' approach beside the requirements made by users, the demands of the local and wider community, special interest groups, such as NGOs, etc. have been increasingly taking into account; activist approach - the highest level of ecological sensitivity and engagement of modern organizations tend not only to improve their business but also environmental success. 


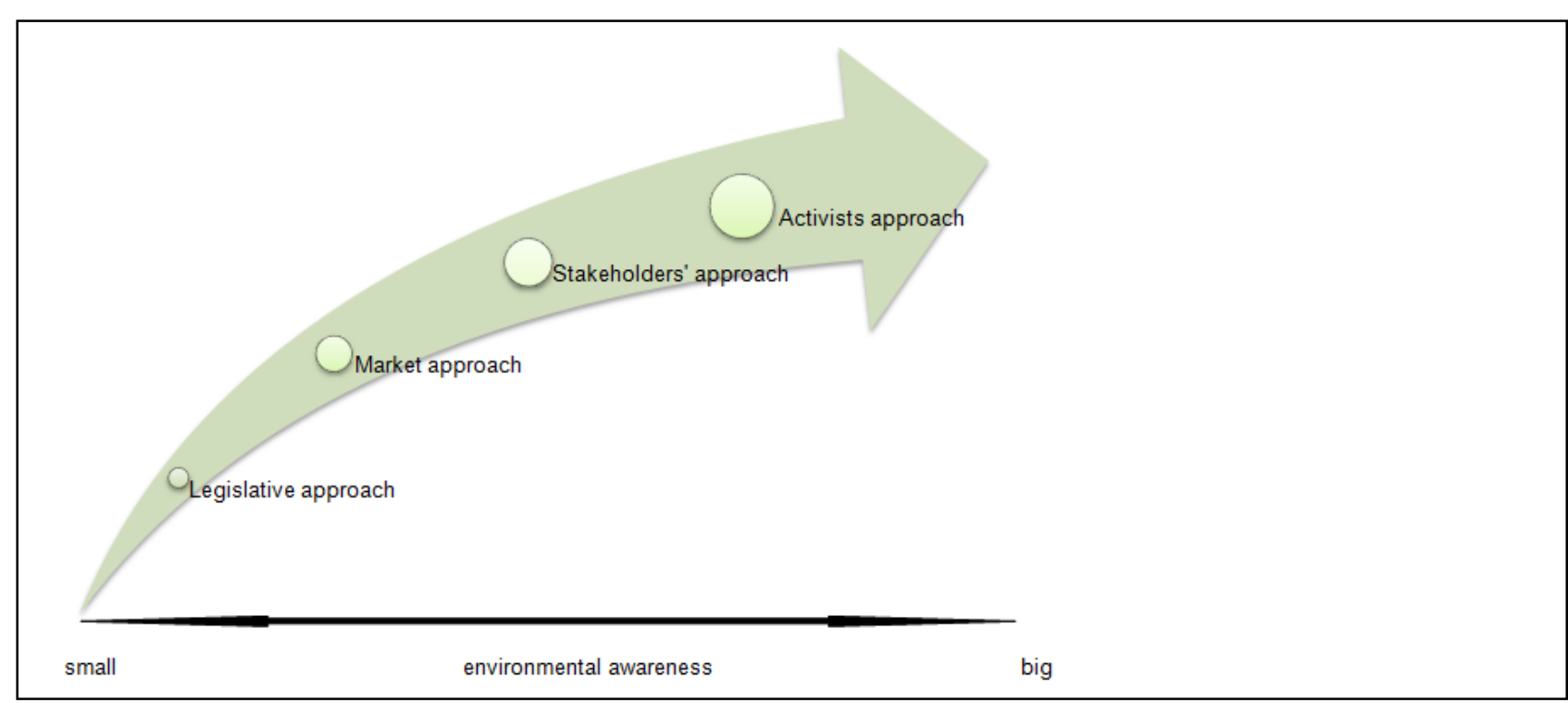

Fig. 1. Organizational approaches to the environmental problem

These approaches suggest the need to strengthen environmental awareness and to improve environmental behaviour in all phases of the project life cycle, with the aim that the product, as the project result, together with competitiveness, becomes environmentally friendly. All this requires constant innovation and development of management approaches and processes. In this way one can reach the innovative approach to project management that is based on the integration of organizational approaches to the environmental problem and adaption of different approaches to the project management.

\section{Project management innovative approach to produce an environmentally friendly product}

Today we are faced with increasing environmental problems such as reduction of natural resources, global warming, environmental pollution, problems with waste management, etc. On the other hand, the level of knowledge in various fields of science and state-of-the-art technology are so advanced that we can talk about solutions that can protect the environment and prevent its pollution. The primarily thought here is focused on changes on products so that they become environmentally friendly, but also on the processes and policies such as reduction in energy consumption and waste production, use of environmentally friendly and sustainable resources and the like. (Bahtijarević-Šiber et al., 2008)

With environmental, legal and market demands that are placed in front of the projects, understanding of project management methodology has significantly begun to change. Together with the need for implementation of formal project management processes, solutions for specific environment in which the project takes place have already been largely introduced. For example, for the successful work on projects that result in new products, in addition to the immediate areas of project management, project environment and the legal framework, the pollution that is made during the product production, method of waste disposal during the project implementation as well as the vision of product treatment after its use should be taken into account. 
The development of new product can be divided into two successive stages (Radaš , 2002): design stage (identification of opportunities and design) and strategy of introducing phase (testing and market introduction).

In the design phase environmental impact assessment is made, and here, most project managers fall into the trap because they only take into account life cycle of the project for a new product development, forgetting its result - product. It has been already said that the project management cycle and product life cycle are not the same because the project can be only one phase in a new product development, that is, product life cycle is much longer than the life cycle of the project necessary for its development. Therefore, when the environmental impact is assessed, it is important to think about the questions such as what is happening with the product after it is introduced to the market, how much it will pollute the environment during its use and after its use.

That is why modern and serious organizations develop a new production paradigm "three zeros" (0-0-0) (Bahtijarević-Šiber et al., 2008): 0 errors, 0 stocks and 0 wastes and emissions.

That means that they are accepting the idea of sustainable development, they are applying an activist approach to the environmental problems, run business in a way that protects natural environment and thus meet the needs of current generation without endagering future generations and their needs. This requires expansion of activities related to the strengthening of environmental awareness and environment protection and development of innovative project management approach in a new product development that will represent integration of different approaches to the project management, and will incorporate the $0-0-0$ paradigm through all stages as well as in the post-project period (during product life cycle).

If it is shown as in the following figure:

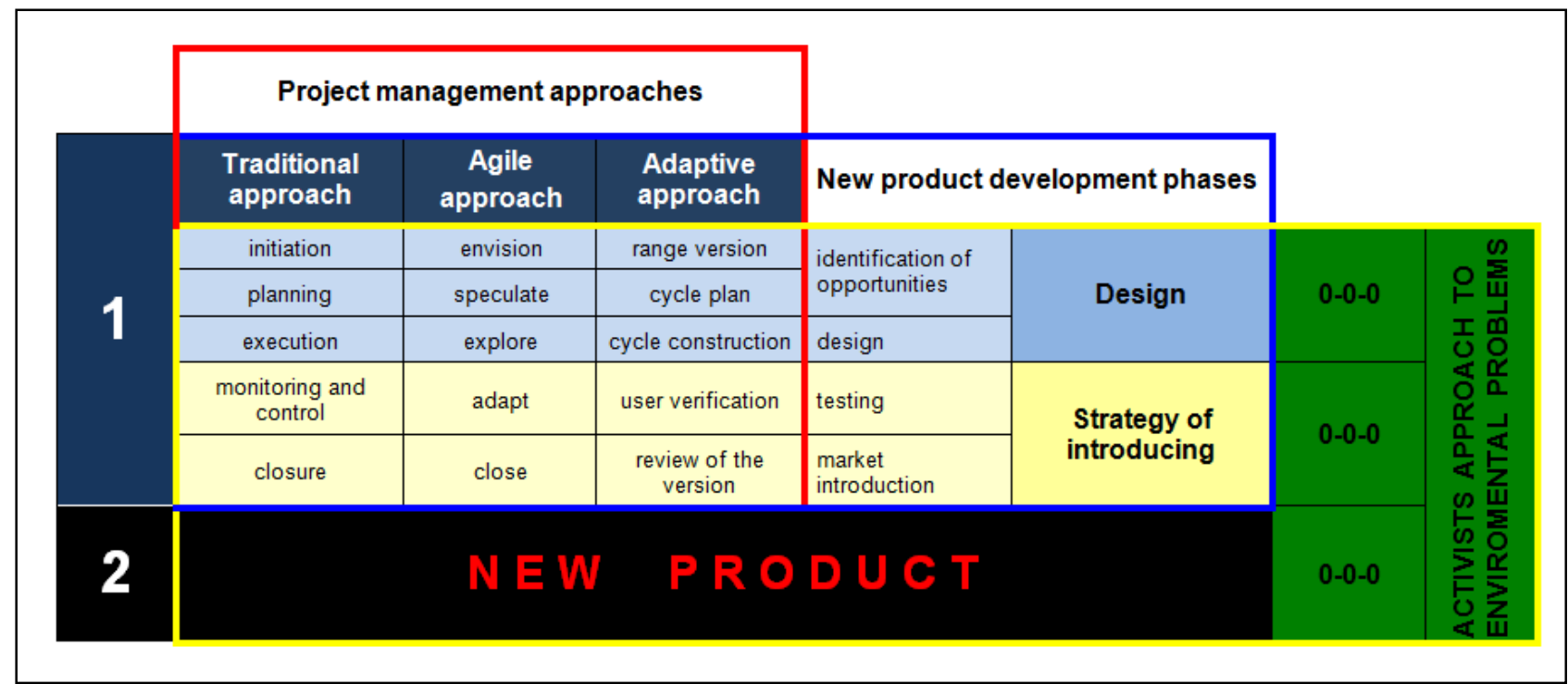

Fig. 2. Integration of the project management approaches of a new product development focused on more effective environment protection

We can say that regardless which project management approach of these is used, basic features of environmental protection have been incorporated in each phase of the 
project life cycle within new product development (1) as well as in the second phase of the product life cycle - the post-project phase (2), that means its use and waste disposal after the use, incorporate basic characteristics of environment protection.

Final goal is to get $100 \%$ environmentally friendly product. With this integrated approach to project management of a new product development it is possible to make influence on efficient / better environmental protection and thereby to ensure sustainability of natural resources and sustainable development.

\section{Conclusion}

As it is becoming clearer, in the future, challenges important for the environment protection and preservation, including projects for environmentally friendly products development, will be imposed on the projects, and together with these new requirements, new approaches to project management will be developed. Therefore, for the successful work on projects that lead to new products, in addition to immediate areas of project management, project environment and legal framework, pollution that is made during a product production, method of disposal of waste produced during project implementation and vision of product treatment after its use should be taken into account.

All this requires continuous improvement of management approaches and processes by which it is possible to reach a new approach to the project management based on the integration of legal, market, activists and other approaches involved in different project management approaches in development of a new product which will be environmentally friendly.

\section{References}

A Guide to the Project Management Body of Knowledge, 4th Edition (PMBOK Guide), Project Management Institute (PMI), Pennsylvania, USA, 2008 Bahtijarević-Šiber F., Sikavica P., Pološki - Vokić N., Suvremeni menadžment (Modern management), Školska knjiga, Zagreb, 2008

Majstorović, V., Projektni menadžment (Project management), Sveučilište u Mostaru (University of Mostar), Mostar, 2010

Manifesto for Agile Software Development, <http://www.agilemanifesto.org/>

Padavić I., Velić M., Ljubobratović D., Agilni razvoj programskih proizvoda (Agile software development), INFOTEH-JAHORINA Vol. 10, Ref. E-I-16, 2011. <http://infoteh.etf.unssa.rs.ba/zbornik/2011/radovi/E-I/E-I-16.pdf>

Radaš S., Razvijanje inovacija u Hrvatskoj (Innovation development in Croatia), Privredna kretanja i ekonomska politika, No.89, 2002

Špundak, M., Upravljanje projektima - definicije i metodologije (Project management - definition and metodologies),

〈http://bme.unizg.hr/_download/repository/kvalifikacijski_clanak.pdf>

Wysocki R.K. and McGary, R. Effective Project Management, Third Edition. Indianapolis, IN: John Wiley \& Sons, Inc, 2003 